\title{
LA UTILIDAD DE LO EFÍMERO EN EL ESTUDIO DE LA LENGUA DEL S. XIX: CUESTIONES GRAMATICALES A TRAVÉS DE LA PRENSA ${ }^{1}$
}

\author{
Miguel ÁNGEL PUCHE LORENZO \\ Universidad de Murcia \\ mapuche@um.es \\ ORCID: 0000-0002-3544-6382
}

\section{RESUMEN}

La prensa, durante el siglo XIX, se convierte en el medio idóneo para difundir y exponer las más diversas cuestiones. A causa del alcance social adquirido, es el texto escrito de mayor trascendencia de este periodo y en él adquiere especial protagonismo la lengua. Por ello, las opiniones vertidas, los debates planteados o la propagación de nuevos modelos lingüísticos aparecidos en sus páginas permiten destacar la utilidad de este medio efímero para la evolución de la lengua española, relativa a un periodo poco atendido. El análisis de determinadas cuestiones gramaticales será un claro ejemplo de su importancia y de que, probablemente, determinados cambios se propagaron o se dataron por vez primera en sus páginas.

PALABRAS CLAVE: historia de la lengua española, siglo XIX, prensa, periodismo, cambio lingüístico.

\section{THE USEFULNESS OF THE EPHEMERAL IN THE STUDY OF THE LANGUAGE OF THE NINETEENTH CENTURY: GRAMMATICAL QUESTIONS THROUGH THE PRESS}

\section{ABSTRACT}

The press, during the $19^{\text {th }}$ century, became the ideal means to disseminate and expose the most diverse issues. Because of the acquired social scope, it is the most important written text of this period and in it the language reaches special prominence. Therefore, the opinions expressed, the debates raised or the propagation of new linguistic models appeared in its pages allow us to highlight the usefulness of this ephemeral means for the evolution of the Spanish language, related to a period little studied. The analysis of certain grammatical questions will be a clear example of its importance. In addition, it's very likely that certain changes were propagated or were first reported on its pages.

KEYWORDS: history of the Spanish language, $19^{\text {th }}$ century, press, journalism, linguistic change.

\section{INTRODUCCIÓN}

La prensa adquiere en el siglo XIX una destacable importancia, al convertirse en el reflejo de los diversos sentimientos y actitudes de la sociedad española. Dejado atrás el modelo dieciochesco, se dio paso a un medio a través del cual se

\footnotetext{
${ }^{1}$ Este trabajo se ha realizado en el seno del proyecto PGC2018-093527-B-I00, financiado por el Ministerio de Ciencia, Innovación y Universidades.
} 
difundían las tendencias e ideologías políticas, en un primer momento, para continuar evolucionando, ya a mediados de ese siglo, hasta la prensa informativa, es decir, al periódico preocupado por contar noticias y no tanto por exhortar ideas, que culminaría en el surgimiento del sensacionalismo informativo auspiciado por el crimen de la calle Fuencarral, en julio de 1888 (Barrera 2000: 18-23). ${ }^{2}$ Por ello, a pesar de su carácter efímero, se puede considerar como material de enorme valor para reconstruir la historia de una sociedad, desde las más variadas perspectivas, y también del idioma que le permite comunicarse. Desde tiempos relativamente recientes, esta representación textual está siendo objeto de atención por parte de los investigadores de la historia de la lengua, ${ }^{3}$ que acuden a este tipo de fuentes para completar todo lo que hasta ahora se ha venido afirmando o estudiando a partir de corpus de otra naturaleza ${ }^{4} \mathrm{O}$, incluso, para ahondar en algunos periodos poco atendidos del estado evolutivo del idioma. A través, por tanto, de la prensa del siglo XIX se ha configurado un amplio conjunto documental para comprobar cómo la lengua, convertida en noticia, es analizada desde diferentes perspectivas. De ese modo, la utilidad de esa producción efímera quedará demostrada, pues se entenderá «utilidad» en el sentido del beneficio que proporciona a la disciplina objeto de estudio además de aquellos que menciona Ordine, a quien se ha recurrido para ampliar los efectos designativos de esta palabra, así como por coincidir en el interés de «interrogar el pasado para comprender el presente e imaginar el futuro» (Ordine 2013: 96).

Un aspecto que ha provocado interesantes discusiones y debates ha consistido en pergeñar la filiación de esta producción textual, en adjudicar la pertenencia a uno u otro género. Este proceso es complejo, aunque es, durante el siglo XIX, cuando se localizan las posturas que más nos interesan. De hecho, Juan Francisco Pacheco dedicó al periodismo el discurso de ingreso en la Real Academia en $1845 .{ }^{5} \mathrm{~A}$ pesar de estar vinculado al ámbito político, el autor había

2 Este trabajo no tiene la intención de realizar una historia de la prensa o del periodismo españoles. Para conocer estos aspectos y, en concreto, el proceso evolutivo que se desarrolla en el siglo XIX, se puede consultar, entre otros, Seoane (1983) y Fuentes y Fernández (1997).

${ }^{3}$ La producción de este tipo textual fue objeto de atención de trabajos pioneros en este sentido como los de Battaner (1977), Pochat Muro (2015 [1982]), Gutiérrez Cuadrado (1988) o Gómez de Enterría (1993), junto a otros investigadores que se interesaron por la producción de autores literarios en este medio, como es el caso de Risco (1972).

${ }^{4}$ Para corroborar el interés que empieza a despertar el texto periodístico desde la óptica de la historia de la lengua, se puede consultar Lara (2015: 466-467), donde se incluye, dentro del siglo XIX, un apartado referido a esas cuestiones mostrando cómo la prosa «fue adquiriendo una viveza y una economía de medios, que contrasta con el lento desarrollo de las ideas y los párrafos largos y llenos de digresiones, propios del siglo anterior».

${ }^{5}$ En ese año fue elegido como académico honorario y en 1847 se convirtió en académico de número. El discurso pronunciado, en el que abundan las palabras de gratitud, así como el interés por el periodismo, fue publicado el 22 de junio de 1845 en el periódico El Tiempo. Se indica que no fue hasta 1848 cuando se reguló el acto de ingreso en la docta institución y se pasó a publicar el discurso de ingreso junto con la contestación del académico correspondiente (Álvarez de Miranda 2011: 17). Algunos de estos discursos no eran tan breves y adquieren un especial valor 
utilizado la prensa para difundir sus ideas y lleva a cabo una contextualización de este medio al afirmar:

Me refiero, señores, al periodismo, creación de la presente época, signo y expresión de la actividad que nos devora, menos aún garantía, como le llaman, de las libertades y las instituciones, que instrumento de combate para la batalla interna y continua en que vivimos y nos ajitamos. Me refiero al periodismo, que los insignes fundadores de esta Academia ni conocieron, ni alcanzaron á prever; que la generación última pudo todavía calificar desdeñosamente; pero al que nosotros debemos hoy considerar de un modo serio y grave, porque es serio el lugar á donde se ha levantado, y grave é importante el destino que le corresponde en nuestra edad, y que cada dia ha de corresponderle mas de lleno. (Tiempo 22/6/1845)

Consciente de la repulsa que la Real Academia venía realizando a las novedades, introduce su peculiar defensa, a pesar de que él mismo hubiera condenado y criticado a la prensa periódica con anterioridad:

Señores: yo he principiado hablando con una justa dureza del periodismo. y no pienso seguramente retractar ninguna de mis palabras. Le he llamado tosco, desaliñado, procaz [...] le he acusado de desconocer el diccionario, de conculcar la sintaxis española. Sin embargo, lo que tiene un objeto propio; lo que se reviste de una forma especial; lo que en ese objeto y en esa forma puede remontarse, y se ha remontado de hecho, merced al talento de grandes escritores, interesando, cautivando, arrastrando á toda clase de personas; lo que se presta á una belleza indudable, y á una sublimidad mas indudable aún; esto, señores, no es digno de desprecio [...] El ingenio y el arte se han aplicado vivamente al periodismo. (Tiempo 22/6/1845)

Tras esas palabras se inclina a defenderlo como un género literario más, incidiendo en que su carácter efímero lo diferencia de los grandes géneros tradicionales:

\begin{abstract}
Si el periodismo comenzó como un hecho instintivo, y no otra cosa, encaminado á la esfera política, y no á la literaria; en el día es ya un hecho reflexivo, una obra de arte, una alta producción del ingenio militante y febril, como ya la llamé, bastarda, sí se quiere darle este nombre; pero literaria siempre, y de una especie de literatura viva, espontánea, agitadora, infiltrada en la sociedad hasta la médula de sus huesos, afectándola y removiéndola más que otra ninguna. [...] Género literario, que ha principiado como todos los géneros por una completa espontaneidad; pero que en el día debe ser, como lo son también todos, una obra de la naturaleza y del arte [...] ¿Quién lee, señores, un artículo de periódico, pasado el día, pasados los momentos, para los cuales se escribió? [...] Impídelo, no puede dudarse, la índole misma, el género de la composición, que, escrita principalmente para causar efecto
\end{abstract}

para la historia de nuestra disciplina. Es el caso del de Pedro José Pidal, pronunciado el 22 de febrero de 1844 y publicado el 25 de abril de ese mismo año en el [Palma] Almacén de frutos literarios del Semanario de Palma, cuando fue recibido como Académico honorario. En sus páginas incide en las Partidas como obra que ocasionó el nacimiento del español jurídico marcando, de ese modo, la larga tradición que tiene nuestra lengua en la expresión de esos conocimientos especializados. Es necesario señalar que los periódicos citados en el desarrollo de este trabajo han sido consultados a través de la Hemeroteca digital de la Biblioteca Nacional de España y del Portal de Prensa Virtual Histórica. Al final se recogen todas las fuentes citadas. 
en determinados instantes, han menester de otra especie de belleza que la que demandaría para causarlo al cabo de años, al cabo de siglos. (Tiempo 22/6/1845)

A finales de ese mismo siglo, en 1895, Eugenio Sellés retomó la caracterización del periodismo en su también discurso de ingreso en la Real Academia. En él aparece la cuestión del género literario, su influencia en la sociedad y la lengua utilizada en este medio, a la vez que traza su evolución histórica. De hecho, en su comparación con el libro, indica que «El libro tiene demasiado peso para andar a la lijera, por eso va quedándose atrás. El periódico ocupa menos, habla con rapidez y pasa sin rastro profundo: por eso va tomando la delantera» (1895: 23). Subyace la idea de medio efímero, aunque ha adquirido un peso social considerable, aspecto este que, en cuestiones de modelos lingüísticos, se explica porque «Háblase con llaneza adecuada á la realidad y al entender común, y aún se advierte cierto amor a lo castizo, por el cual amor la prensa ha restaurado no pocos giros y palabras antes en desuso» (1895: 23), pues, a pesar de ser criticado por aquellos escritores que también lo utilizan, «los periódicos, si no han enseñado con su modelo á escribir á ningún literato, han enseñado á leer a mucha gente que no sabía. Conquista firme para la cultura» (1895: 23). De esa apreciación surge una definición que recoge un aspecto de enorme valor para la prensa, al afirmar que «el periódico es el libro del pobre» (1895: 34-35).

A raíz de los testimonios directos del siglo XIX, se advierte que la prensa se consolida como el medio de difusión de los aspectos más diversos y que, con el paso del tiempo, se amplía su extensión a todos los estratos o estamentos que componen la sociedad decimonónica. Sin embargo, su estudio es complejo, puesto que en él se introducen géneros textuales variados, ya sean crónicas, creaciones literarias, artículos de opinión, escritos satíricos, anuncios, cartas que muestran la interacción con los lectores, etc., por lo que el periódico, como ha afirmado Borreguero (2012: 310), se configura «como una colección de textos con finalidades comunicativas, estilos de prosa y organización interna netamente diversas». ${ }^{6}$

Estas apreciaciones iniciales permiten corroborar la utilidad de estas fuentes para el estudio de la Historia de la lengua española, sobre todo, para una

${ }^{6}$ El periódico con carácter informativo, como difusor de noticias, parece afianzarse en la segunda mitad del siglo, aunque existan precedentes anteriores de corta existencia (Barrera 2000: 20). En este sentido, cabe recordar las palabras de Alberto Lista, escritas a principios de siglo, mediante las que queda patente la intención de renovar el formato de un periódico: «Es harto conocida la influencia de los buenos periódicos en la instrucción de las naciones. Son los vehículos por donde pasan los conocimientos útiles de la clase instruída que por su profesión cultiva las letras, al resto de los ciudadanos», de hecho, un periódico debe ampliar sus perspectivas pues «Las noticias de los nuevos descubrimientos y de los libros mas interesantes que se publiquen nuevamente, los artículos de historia y necrología, los análisis y exámenes de los libros recientemente publicados deberán por lo menos alternar con los artículos de reflexiones políticas» (Gazeta de Sevilla, 13/2/1810) (ápud. Gómez Ímaz 2008: 162 y ss.). 
época considerada como poco atendida desde determinadas perspectivas y en las que se está profundizando en la actualidad. Del mismo modo, el discurso de Pacheco funciona, en cierta medida, como punto de inflexión porque da a conocer un cambio de actitud hacia el periodismo desde la institución que vela por la norma del español. En consecuencia, este hecho facilita acotar temporalmente las publicaciones que actuarán de soporte para este trabajo. El lapso temporal que se utilizará en esta ocasión comprenderá el reinado de Isabel II (1833-1868), momento en el que se contextualizan las palabras de Pacheco. La lectura y el vaciado de los periódicos publicados en esos años proporcionarán los materiales que se estudiarán a continuación, utilizando para este fin los recursos digitales que ofrece la Hemeroteca digital de la BNE y la Biblioteca de la Prensa Virtual Histórica. ${ }^{7}$

\section{HOJEANDO Y OJEANDO. LAS NOTICIAS SOBRE LA LENGUA}

La presencia de la lengua en los diferentes textos que componen cualquier medio periodístico puede realizarse de forma directa o indirecta. En el primer caso, y a grandes rasgos, la lengua es objeto de la noticia tanto porque sea consecuencia del contenido de una obra de carácter lingüístico y se procede a su comentario, crítico o adulatorio, como por el hecho de que haya una forma o estructura que por la novedad o la impropiedad que manifiesta, principalmente, proporcione motivos suficientes al redactor para sustentar su opinión al respecto. Cuando esta visión es crítica, se puede llegar a encontrar cierto diálogo periodístico entre diversos medios o entre redactores o escritores que mantienen opiniones enfrentadas al respecto. Dentro de este apartado, se incluiría otro fenómeno vinculado al mercado editorial pues habrá determinadas publicaciones, referidas al estudio de la lengua, que se difundirán desde el periódico en varias entregas, dado que este era un medio rápido y más económico que el libro. Por otra parte, y en segundo lugar, se entenderá por testimonio indirecto cuando la noticia en cuestión aborde cualquier tema, alejado siempre del ámbito lingüístico, aunque en su redacción se introduzca alguna explicación o glosa sobre determinadas palabras, expresiones, construcciones, usos ortográficos o expresión oral o escrita de un individuo, principalmente. En ocasiones, este escolio viene motivado por la intención satírica que ciertos ámbitos, como el político, proporcionaban. Así mismo, no se puede obviar que existen otros mecanismos para indicar la actitud lingüística del escritor-redactor ante la lengua que utiliza. Para ello, se recurre a procedimientos ortotipográficos, como el uso de cursiva, versalitas o negrita, mediante los que se marca la intertextualidad entre publicaciones, las expresiones o palabras extranjeras, vulgares, coloquiales o dialectales, los modismos, los usos irónicos o satíricos o la reproducción directa de lo

\footnotetext{
${ }^{7}$ La utilidad de las fuentes digitales para el estudio lingüístico se indica en Campos (2018) o Cotelo (2019), en el caso concreto de la elaboración del Nuevo diccionario histórico del español.
} 
manifestado por otra persona. En definitiva, esta marcación dejaría patente el alejamiento de esa estructura de la norma o, en el contexto histórico señalado, de la pureza del idioma (Rivas Zancarrón 2018: 272-273). ${ }^{8}$

\title{
2.1. La lengua como texto de la noticia
}

Las noticias sobre la lengua, en cualquiera de sus aspectos, suelen hallarse en apartados que reciben distintas denominaciones, como Variedades, Sección literaria, Filología, etc., dependiendo del contenido y de la finalidad del periódico; o, sencillamente, la columna en cuestión puede llevar el título del contenido que se va a exponer. Los temas relacionados con la lengua que se encuentran recogidos en estos apartados ponen de manifiesto el interés social por el idioma desde las más variadas perspectivas: institucional, educativa, normalizadora, editorial, gramatical, etc. Ello queda representado, por ejemplo, en la acogida que recibieron los discursos académicos en el seno de la prensa del momento, tal como se cita en la parte introductoria de este trabajo. ${ }^{9}$ Esta actitud y predisposición informativa a recoger tales contenidos evidencian la expectación social que suscitaba todo lo que emanaba desde el ámbito académico y, además, su repercusión era inmediata, puesto que la aparición del texto se producía con anterioridad al impreso, donde se recogía el discurso y la contestación del académico correspondiente. No obstante, a pesar de resultar de interés la acogida de este tipo textual en la prensa decimonónica, la opinión que merecen esos discursos es indicativa de la importancia que prestaba parte de la sociedad ante los asuntos concernientes a la lengua. Es el caso del comentario que suscita el discurso de Eugenio de Ochoa, ${ }^{10}$ por ejemplo:

\begin{abstract}
Nos hemos tomado el duro trabajo de leer el discurso de recibimiento pronunciado por el señor don Eugenio de Ochoa en la Academia Española, y decimos duro trabajo, porque á lo humilde del estilo reúne el estar lleno de insulsas vulgaridades y adolecer no poco de estravío en la colocación de las ideas. Desde luego no sabemos donde ha oido reputar como escritores clásicos, como padres de la lengua á Campomanes y Antonio Pérez, á no ser que lo haya tomado de algún libro francés. Pero lo que mas nos ha sorprendido es lo airado que se muestra contra los galicismos cuando él es el que mas incurre en ellos. Entre los muchos que pudiéramos citar, tenemos presente ahora que por dos veces habla de la masa
\end{abstract}

8 Centrado en la prensa americana, Rivas Zancarrón (2019) propone este proceder ortotipográfico para el estudio de actitudes explícitas, pero también implícitas ante la lengua, aunque sea necesario su análisis en contraste con otras tradiciones discursivas.

9 Se han citado ya los discursos de Pacheco y Pidal con anterioridad, pero su aparición en la prensa no constituye una excepción, pues se recogen los de Alcalá Galiano, leído el 28 de diciembre de 1843 ([Heraldo] El Heraldo 4/1/1844: 4), José J. de Mora, leído el 10 de diciembre de 1848 ([Popular] El popular 16/12/1848: 1-4) o el de Pedro Felipe Monlau, leído el 29 de junio de 1859 ([Clamor] El clamor público 1/7/1859 y 2/7/1859: 4), por citar otros ejemplos representativos.

${ }^{10}$ Fue elegido académico honorario en 1844 y pasó a ser de número en 1847. 
de la Nación y de las masas populares. Nosotros no conocemos otras masas que las de los pasteles. (Clamor 26/9/1844: 3) ${ }^{11}$

\section{El de Antonio Alcalá Galiano: ${ }^{12}$}

Todos los periódicos de la situación hasta el nuevo Avisador, han publicado un discurso pronunciado por D. Antonio Alcalá Galiano al tomar asiento en la academia española, á la cual han hecho un flaco favor en ello, asi como á su nuevo individuo, ya por el color político que se da á la corporación contra su constante independencia, ya por la pobreza de dicho discurso y las ideas que contienen desfavorables al proceder de aquella. Este documento es también notable por las erróneas opiniones políticas y literarias que vierte, de que vamos á hacer una ligera reseña [...] Si juzgamos este discurso por la parte literaria para optar el honor académico, vemos ser inferior á los que frecuentemente publican otras corporaciones, y nada arriesgaremos en añadir que si hubiese sido presentado para obtenerlo, no hubiera merecido los sufragios de la academia de la lengua española. Su lenguaje ni es limpio, ni fijo, ni menos dá esplendor, cuyas cualidades forman el lema de aquellos periodos claros y cortados á la francesa, y no los llanos y sonoros de la nuestra [...]. ([Libertad] El genio de la libertad 30/1/1844: 1-2)

O, por último, el de Javier de Quinto ${ }^{13}$ que fue motivo de airadas disputas entre determinados periódicos. De hecho, los diarios aragoneses publicaron loas

${ }^{11}$ En este mismo periódico continuaron las críticas en días posteriores, de hecho, se llega a decir: «Cuanto mas leemos el discurso, oración o como quiera llamarse, pronunciado en la Academia de la lengua por el señor Ochoa, mayor es nuestra admiración por los elevados conceptos, la pureza del estilo y los primeros de elocución en que abunda tan magnífico modelo de elocuencia franco hispana. Entre las muchas lindezas, que por no incurrir en la nota de pesados nos abstenemos de indicar resalta la preciosísima esclamacion con que termina el segundo período: La lengua está en peligro. El mismo demonio es el señor Ocboa. Solo al académico de nuevo cuño se le podía ocurrir una chanza tan pesada como la de hacernos creer que estamos espuestos á quedarnos mudos, cuando mas necesaria puede sernos la lengua. No cabe cosa de mejor gusto que esas aclamaciones enfáticas y altisonantes en una oración puramente escolástica y gramatical y encajaba á las mil maravillas eso de ¡La lengua está en peligro! como si digéramos, la patria se hunde, la libertad perece, el Estado se desmorona También hallamos poco después un tesón convencido que vale un Perú. Tendrán que ver los tesones convencidos; pues se nos hacen mas duros de convencer que una piedra. Nada menos singular nos parece que mostrándose tan español el señor Ochoa, vaya á recurrir á la opinión de un estrangero sobre achaques de lenguaje teniendo tantas y tan acreditadas autoridades en España. El nombre de Garlos Nodier, en un discurso dedicado á recomendar la fuerza en la dicción hace el mismo efecto que una cartilla francesa, en una escuela de primeras letras. Lo que dice Mr. Nodier acerca de la introducción de voces forasteras, es cosa que todo el mundo sabe, hasta los estudiantuelos, y no valía la pena que el nuevo académico lo citase, para darnos esa prueba de su erudición traspirenaica. Y ya que tan escrupuloso y rígido se muestra, no queremos despedirnos de su merced, sin advertirle que las palabras pensamientos, condición, masas y prensa, que emplea con la mayor frecuencia, no son castizas, ni las usaron nunca nuestros buenos prosistas en el sentido que lo hace el flamante académico. Los castellanos rancios decimos conceptos, circunstancias, multitud ó generalidad, ó imprenta» (Clamor 29/9/1844: 3).

${ }^{12}$ Alcanzó a ser académico de número en 1847, aunque había sido elegido previamente académico honorario en 1843.

${ }^{13}$ Leyó su discurso de ingreso en 1850. Referido a la influencia francesa, no solo en el léxico sino también en giros y expresiones, propone acciones que implican al Gobierno y a la propia 
en sus páginas, mientras que otros fueron más críticos. A raíz de ello, surgió un proceso de interacción entre la sociedad y la prensa, por una parte, y entre las diversas publicaciones, por otra:

Contestación á la defensa que el DIARIO DE ZARAGOZA hace del discurso de don Javier de Quinto, y al proemio que LA ESPAÑA le añade, al reproducirla integra en sus números 580 y 581, correspondientes al último dia del pasado y al primero del presente mes. Una mala causa nunca puede tener buena defensa. El discurso académico del señor don Javier de Quinto, como quiera que (1) es pobre y desaliñado, según la justa calificación que irónicamente le ha sabido dar su propio autor, ni el DIARIO DE ZARAGOZA, ni LA ESPAÑA, ni nadie, será capaz (2) de variar su esencia. Convencido, como estoy de esta verdad, al contestar á los que al ser amigos ó paisanos del señor Quinto, con tanto empeño defienden lo contrario, pienso ser breve y conciso en cuanto pueda [...] para hacerme decir muchas cosas, que yo ni siquiera me había imaginado, con el laudable fin de reconstruir la reputación literaria de su paisano, que por lo visto se hallaba en inminente peligro, no creo yo que con su defensa haya conseguido sino lo contrario de cuanto deseaba. (Clamor 15/3/1850: 3-4)

Los tres discursos elegidos tienen un hilo común: el galicismo. Aunque abordado este de formas muy diversas entre ellos, esa tendencia común ratifica la dimensión social que había obtenido el interés de la influencia de la lengua francesa sobre la española. ${ }^{14}$ Sin embargo, dentro de las secciones que se han señalado, encuentran un hueco otras producciones de carácter lingüístico que no soslayan la atención que recibe cualquier texto preocupado o que centre su objeto de estudio en la lengua. Las obras de índole gramatical ocupan un lugar

Academia y vayan enfocadas a cuestiones educativas y el apoyo a la propia Academia. De hecho, considera que esta institución debería sancionar las voces nuevas que se introducen en el idioma (Clavería Nadal 2016: 127-129).

${ }^{14}$ Relacionado con este asunto, destaca el hecho de que se localicen comentarios laudatorios ante la publicación de algunas obras que vendrían a solventar el buen uso de las palabras atendiendo al origen que poseen. Es el caso de la columna dedicada al Diccionario matriz de la lengua castellana de Baralt, obra inconclusa, aunque se dijo de ella: «Diccionario matriz de la lengua castellana, por Don Rafael Marta Baralt. Prospecto y muestra de la obra. Entre la multitud de impresos que inunda nuestra literatura á ochavo el pliego generalizando la lectura, pero envileciendo el valor de los buenos originales después de destruirse unas á otras las empresas de baratillo, suele aparecer una obra concienzuda, útil, laboriosa y de pocas ganancias, pero que promueve y adelanta el verdadero saber y señala á las generaciones futuras nuestro paso por el mundo en este siglo de frivolidad para el estudio y atento solo á la sensualidad y al dinero. La obra del señor Baralt, colosal por su estension, útil por su esencia y por su forma, es de las que hacen época en la historia filológica de un país [...] ¿Qué escritor, teniendo á mano este libro, conservará la duda que muchas veces nos ha asaltado á nosotros de escoger la mas propia entré dos voces tenidas por sinónimas? Desapareceria entonces la ambigüedad de las leyes que nace de la diversa inteligencia de las palabras, la vaguedad de los escritos científicos, la algaravia de los escritores adocenados y esa pomposa abundancia de voces de que se lamentaba Capmani, comparándola por su vaciedad á una mesa que fundase la ostentación de su riqueza en el número de platos mas no de los manjares que contienen» (Clamor 5/3/1851: 3). 
destacado, pues si a unas las mueve una notable inclinación docente, como sucede con la publicada por García de Villalta: ${ }^{15}$

\begin{abstract}
Hemos visto anunciada en estos ultimos días una Gramática de la lengua Castellana para el uso de las escuelas por D. José García de Villalta. Cuando nuestra antigua aficion á esta clase de estudios no nos hubiera movido á ocuparnos desde luego en el examen de un trabajo tan útil, el solo nombre del autor, que posee nuestra lengua con la perfección y conocimiento que demuestran sus escritos, nos habría inducido á enterarnos de sus ideas; [...] La dificultad está en acertar á esplicarlas de manera que se pongan al alcance de los que han de aprenderlas, incluso mas si estos son niños como los que concurren á las escuelas [...] La primera condición que se exige es la claridad, y esta la hemos encontrado felizmente en la obra que examinamos [...] La lengua castellana necesita una gramática. Parece que la academia española se está dedicando á este trabajo, cuyos frutos se hacen aguardar demasiado, ó á lo menos algo mas de lo que exije la pública impaciencia [...] A nuestro modo de ver, el grave defecto de todas las gramáticas mas comunes ha sido el de haber considerado este estudio meramente como preliminar al de la lengua latina. De aquí es que las palabras se han clasificado mal, que se han hecho declinables por casos las que no lo son: que los tiempos de los verbos se han trocado en el concepto que encierra su equívoca terminación, que se han dado reglas de mas y se han omitido otras muy esenciales. ([RL] Revista literaria de El español, 29, 6, 1845, 1-3)
\end{abstract}

Otras veces, dado el contexto político y social de ese momento histórico, se llega a utilizar la obra gramatical como centro del que emerge una vertiente satírica y crítica con esa situación. Ese proceder no exime a la Academia de recibir su pertinente comentario negativo al no cumplir con sus obligaciones en materia lingüística:

GRAMATICA CASTELLANA DEMOCRATICA. Encargado de la educación moral y literaria de mi hijo adoptivo Sanchico, y observando que la Gramática aprobada por la Academia de la lengua, es hoy ineficaz y poco digestiva para la infancia de nuestros gloriosos días, héme propuesto componer una gramática radical-progresista-democráticarevolucionaria, á imitación de aquellos eminentes ciudadanos que escriben Constituciones para los niños. Sirva esta advertencia de preliminar ó prólogo para mi sesudo y meditado trabajo. COMPENDIO DE GRMATICA (sic) REVOLUCIONARIA. PRIMERA PARTE. Introducción. Los sabios andan remisos y vacilantes sin saber á punto verdadero, si la gramática es arte ó ciencia, pero desde que Sagasta emitió sus opiniones en este sentido, se ha convenido en que ni es arte ni ciencia, sino un catálogo ó recopilacion de palabras de las cuales se puede hacer uso sin reglas que estorben ningún pensamiento, mayormente si esto es progresista. El lenguaje hablado y el lenguaje escrito se forma de palabras, y las palabras se componen de letras, cuidando de no confundir estas con las de cambio, hoy vencidas y no pagadas, y para distinguirlas, en lugar de llamarlas letras las daremos el nombre de caractéres. ([Fraile] El Fraile 18/3/1870: 7)

En otras ocasiones, la imposición de un texto con cariz docente de esta naturaleza conlleva la publicación de una ardiente crítica a la obra, de forma directa, y a los nuevos planes de estudios, de manera indirecta. De hecho, en

${ }^{15}$ Conocida es su labor como traductor (Cornejo 2011), tanto del francés como del inglés, aunque se ha venido destacando la importancia de su trabajo en este último caso, principalmente por la traducción de obras de Irving y Shakespeare (Calvo 2002). 
[Español] El español se localiza uno de estos ejemplos. Ocupa una extensa columna donde se comentan los aspectos morfológicos y sintácticos, las categorías gramaticales y los usos lingüísticos que, a consideración del anónimo redactor, son incorrectos:

Garrapatones de un curso de gramática castellana que se ha señalado por testo de esta asignatura en una Universidad de España, en virtud del nuevo plan de estudios. 10 "Idea es la representación ó imagen de un objeto sensible, causada por la sensación que el alma recibe de la impresión que hacen los objetos esteriores en los sentidos"; Quedan, por consiguiente, excluidas las ideas abstractas, y las de los objetos remotos; luego no tenemos Idea de Dios, de la virtud, del polo ártico, ni de Julio César. Luego yo no tengo idea del mal gramático, y pésimo escritor, autor de la presente obra. $2^{\mathrm{o}}$ "El participio es declinable;" por consiguiente se puede decir: las mugeres que yo he vistas. El autor ignora (entre otras muchas cosas) que el participio deja de serlo cuando no se le junta el verbo auxiliar y quando se le junta, no es declinable. El participio se llama así, porque participa de la naturaleza del adjetivo y del verbo, declinable en el primer caso, indeclinable en el segundo. 3ํㅜ P: ¿Qué accidentes son comunes á las partes declinables. R. El número, etc." Esta es concordancia vizcaína. (7/12/1845: 4) $)^{16}$

Junto a estas cuestiones que ensalzan el interés por la enseñanza de la gramática y alcanzaron una proyección considerable desde unos textos «efímeros», teniendo en cuenta los medios y el contexto del siglo XIX, hay que detenerse de forma obligada en el hecho de que el periódico se convierta en el canal idóneo para introducir nuevas aportaciones gramaticales. Muchas de ellas jamás se llegaron a recopilar en libros editados de forma independiente, aunque esto no implicó que estas ideas repercutieran en textos posteriores, además de ser un claro ejemplo de la recepción en España de nuevas corrientes lingüísticas. Francisco Seijas, cuyo nombre completo es Francisco de Paula Seijas y Lozano, ${ }^{17}$ utilizó el periódico La Ilustración para redactar, en varias entregas, un Ensayo sobre las preposiciones. Usó para su introducción las palabras de Balmes, sin embargo, la teoría que sustentó su trabajo sobre las preposiciones es la de Destutt de Tracy, que, en la Mémoire sur la faculté de penser (1796), acuñó la voz ideología "para denominar a la ciencia que estudia las ideas, su carácter, origen y las leyes que las rigen, así como las relaciones con los signos que las expresan» (Calero 2014: 118). De hecho, haciéndose eco la gramática filosófica argumenta lo siguiente:

${ }^{16}$ En total son veintiocho los aspectos cuestionados de este tratado gramatical. La comparación, tras la previa consulta, con las obras publicadas durante este periodo lleva a pensar, en virtud de las múltiples coincidencias y exactitudes de los fragmentos, que se trata del Nuevo Epitome de Gramática Castellana ó metodo sencillo de enseñar la Lengua Castellana por los principios generales á la filosofía comun de las lenguas; arreglado también á la latina para facilitar su estudio. Puesto en diálogo siguiendo los principios de la Academia Española de Luis de Mata y Araujo, publicado en 1842 en La Habana.

$17 \mathrm{Su}$ interés filológico le llevó a colaborar con Aureliano Fernández Guerra en la edición de Cuento de cuentos de Quevedo. Se ocupó, en ese momento, de la explicación de los refranes y frases hechas que en esa obra aparecen, comentarios que después utilizarían Merimée y Sbarbi (Ynduráin 1955: 111). 
Yo, siguiendo á Destutt Tracy, en cuanto asegura que las interjecciones son las primeras voces en el desarrollo histórico, no puedo luego seguirle en su sistema por lo que acabo de esponer, y por lo que voy á manifestar al hablar de las palabras. Estas esplican ó un objeto que tiene una existencia material ó metafísica, la movilidad ó acción física ó moral, en cuyo caso están los nombres y los verbos, ó espresan é indican las relaciones y calidades, la semejanza y ayuntamiento de los objetos y de su acción, en cuyo caso se hallan las demás partes del discurso. A las primeras se les da el nombre de palabras declinables, y á las segundas el de indeclinables. Examinémoslas en conjunto y de ligero, pues no es este el lugar á propósito de entrar en detalles, ni el objeto principal de estas lecciones lo permite. ([Ilustración] La Ilustración 9/10/1852: 3)

Se comprueba a través de estas palabras la importancia que tuvo la interjección para Destutt de Tracy y, probablemente, ello alimentó su tendencia al estudio de otras partículas, en este caso las preposiciones que, dentro de la teoría de ese autor, a pesar de ser secundarias, son necesarias para la 'sutileza de expresión'. Ello llevó a Tracy a retomar la idea «para reforzar su tesis de que las preposiciones son antiguos adjetivos» (Luis 2010: 45). El plan que desarrollará en la entrega segunda es el siguiente:

¿Qué es preposición? - Divisiones. - 1. En cuanto á la forma y uso que tienen en el discurso: preposiciones propiamente dichas: partículas prepositivas: frases prepositivas. Naturaleza de cada una de estas divisiones. - Cuáles pueden llamarse con propiedad preposiciones.-2. División: en cuanto á la relación que indican: de movimiento y de quietud. - Subdivisiones. - 3. División: en cuanto al modo como modifican. Preposiciones de genitivo, etc. - 4. ¿Esta división es aplicable á las lenguas modernas? ¿Rigen en otros casos las preposiciones? ¿Pueden dividirse en modificadoras del agente, de la acción y del objeto? - ¿Cuál de estas divisiones debe seguirse para clasificar las preposiciones? Cuántas hay en castellano. -Clasificaciones. - Comparación con las de varias lenguas: cuadro general de las preposiciones con arreglo á lo espuesto. - Resumen. - Conclusión de la lección 2. (Ilustración 30/10/1852: 4)

Y muestra cómo intentará seguir esa nueva gramática ideológica y filosófica, ya que su fin último consistirá en constatar su uso en la lengua común, aunque para tal menester será necesaria otra entrega en el periódico:18

He dividido en esta lección las preposiciones en tres grandes grupos, siguiendo á los gramáticos. De estos he desechado el primero y el último en parte, considerando que este puede tener aplicación en las lenguas en que haya declinaciones, dejando como valedera y de grande aplicación la división segunda como mas filosófica. En las siguientes examinaré cada partícula por sí, y veremos hasta qué punto nuestra lengua, como todas las demás, ha conservado la naturaleza propia de las preposiciones en el lenguaje común. (Ilustración 30/10/1852: 6)

Merece la pena destacar, también, que, en otras ocasiones, los autores que desarrollan y firman trabajos de naturaleza lingüística disponen de cierta

18 A partir del 27 de noviembre de 1852, comenzaron a aparecer los inventarios de las preposiciones, junto con ejemplos de su uso. Dada su temprana muerte, González de Tejada dedicó una entrañable nota necrológica en la que destacó su labor filológica ([Pintoresco] Semanario pintoresco español 13/7/1856: 1-4). 
autoridad y están vinculados a la Real Academia, ${ }^{19}$ aspecto este que no implica que sus trabajos sean sometidos a crítica y revisión por parte de los lectores. Probablemente, el periódico resultaba el medio idóneo para difundir con inmediatez teorías o aplicaciones diversas, así como poner de manifiesto usos «incorrectos» en la lengua. Por tanto, la denominada «pureza del idioma» puede actuar de sustento de tales opiniones. Así mismo, la entrega por fascículos facilitaba la publicación de esos trabajos que, unas veces, no habrían encontrado hueco en el seno de otras obras, por su breve extensión; mientras que, en otras, se abarataría el coste, precisamente por su mayor extensión, y la inmediatez, junto a la extensión social más amplia alentarían la impresión en este soporte. Este proceder editorial no ha sido valorado con suficiente precisión, puesto que algunas aportaciones resultan totalmente desconocidas en la actualidad. A Antonio Alcalá Galiano, por ejemplo, se le debe la redacción de una columna titulada «De algunas locuciones viciosas hoy muy en uso» que apareció durante tres domingos en el Diario de Palma (20 y 27 de julio y 3 de agosto de 1856). El tema principal que aborda es el del galicismo, al igual que hizo en su discurso de ingreso en la Real Academia. Constata los usos que él considera erróneos y aporta la manera apropiada de integrarlos en español. Culmina la tercera y última entrega con una captatio benevolentiae donde se incluye la finalidad que ha perseguido con su «insignificante» trabajo:

conociendo que el estudio de la lengua es la parte en que mas suelen flaquear los escritores españoles contemporáneos, a él llama la atencion con todas sus fuerzas, aunque flacas, teniendo el atrevimiento de hacer de maestro cuando la leccion vale poco, con mas gusto convidando á superiores ingenios y personas mas instruidas á ayudarle en su tarea, ya reprendiendo lo malo é indicando el modo de enmendarlo, ya por medio de la aplicacion, dando lo que es superior al precepto y lo que no alcanza á dar quien esto escribe, á saber; modelos donde un estilo elegante vaya acompañado de una dicción correcta y castiza. ([DP] Diario de Palma 3/8/1856: 5)

Es necesario destacar, en este contexto, la labor de José Joaquín de Mora, porque su aportación realizada desde el periodismo contiene matices divulgativos de teorías que circulaban por Europa, educativos $\mathrm{y}$, en cierta medida, puristas y normativos. Conocidas son su Colección de sinónimos de la lengua castellana (1855), sus disputas con Bello a través de la prensa (Durán 2016), la publicación del Catecismo de gramática castellana donde aúna la tradición gramatical latina con las nuevas corrientes de la gramática filosófica (Gaviño 2016) y su labor e intereses educativos y pedagógicos, bajo la influencia de esa última corriente gramatical (García Folgado 2016). Menos atención ha recibido, sin embargo, su producción desde el ámbito periodístico español con temática lingüística. Con motivo de su estancia en Londres, probablemente, se hizo eco de

${ }^{19} \mathrm{El}$ hecho de contar con autores prestigiosos en el estudio de la lengua fue una constante en otros medios periodísticos del siglo XIX, como ha desarrollado y estudiado Poch (2018) en el caso de Benot, Unamuno, Cejador y Frauca, entre otros, en La España moderna. 
las lecciones que Max Müller estaba impartiendo en esa ciudad. Ante el interés que suscitaba el origen de las lenguas, la etimología, las leyes de evolución fonética, la gramática comparada, las clasificaciones de los idiomas, la constatación del sánscrito, etc., cuestiones emergentes en Europa a través de Schlegel o Humboldt, entre otros, difundidas en suelo londinense por Müller, Mora pretendió su divulgación en el ámbito hispánico al advertir la importancia que tenían para el avance de la ciencia filológica. Tales circunstancias promovieron la publicación resumida de esas lecciones bajo el título de La ciencia del lenguaje, en La América, dentro de los números correspondientes al 24 de junio y 8 de julio de 1861. La causa principal de su atención se encuentra en las primeras líneas del artículo:

Su principal objeto, que á primera vista tiene todos los visos de una paradoja, es considerar la ciencia del lenguaje como una de las que deben entrar en la clasificación de las físicas, fundándose en la etimología griega de esta palabra, y deduciendo de ella que los fenómenos de la formación y desarrollo del lenguaje, se someten á las leyes de la naturaleza, del mismo modo que el origen y desarrollo de los cuerpos organizados. ([América] La América 24/6/1861: 12)

Pero, tras exponer las lecciones de Müller, realiza una importante reflexión sobre su manera de percibir la actualidad de los estudios gramaticales, con la confluencia de la gramática filosófica y general, y su vínculo con el uso real o, lo que él denomina, el «idioma usual y empírico»:

Se ha observado con razón que jamás han sido tan frecuentados, como en la época presente,
los estudios gramaticales; jamás se han publicado tantos cursos, tantos compendios, tantos
manuales de Gramática Castellana; jamás se ha enseñado con tanto empeño en
universidades, colegios é institutos, y jamás, al mismo tiempo, se ha visto tan corrompido,
tan desfigurado, tan despojado de sus galas y primores el hermoso lenguaje de Castilla.
Este mal ha tomado vastísimas proporciones; penetra en el trato privado, en los
documentos de oficio, en los debates parlamentarios; se mezcla con la tecnología del foro,
sube á la cátedra evangélica, y, con muy pocas excepciones, és la moneda corriente de
nuestra literatura en todas sus ramificaciones. [...] La casi completa extinción del estudio
de las lenguas clásicas, que tal puede llamarse el estado actual de este ramo de instrucción;
la enseñanza enciclopédica que se ha apoderado en mal hora de nuestros establecimientos
literarios; la aparente facilidad de la lengua francesa, y el absoluto predominio que la
literatura ligera de aquella nación ejerce en el público; la mezquina remuneración que se
da á los autores de producciones serias, de un mérito sólido, y escritas en lenguaje castizo;
tales son algunas de las causas que han influido en la propagación del mal que deploramos.
(América 8/7/1861: 6)

El interés por la etimología y la preocupación por el galicismo procuraron la redacción de una serie de cuatro artículos, publicados en el Diario de Palma, que, bajo el título de Filosofía de las palabras, tenían por objeto esos asuntos. Teniendo presente que su discurso de ingreso en la Academia abordó el tema del 
neologismo, se comprende que esta preocupación no era nueva para Mora. ${ }^{20}$ Por ello, incide, desde un primer momento, en la abundante producción lexicográfica y en la importancia del léxico dentro de una lengua:

Debe ser muy grato todos los amantes de la buena literatura española el giro que ha tomado recientemente el estudio de nuestro hermoso idioma. Las obras que se han publicado, en estos últimos tiempos sobre sinónimos, etimología, galicismos, indican la persuasion en que están nuestros literatos de los vicios que infestan el idioma, de la necesidad de poner término este mal, mucho mas grave que lo que aparece los entendimientos triviales. El idioma es una parte esencial de la vida moral de los pueblos; es el reflejo exactisimo de su carácter, de sus opiniones; es el fiel depositario de sus tradiciones de sus vicisitudes; es en una palabra el infalible representante de el gran signo característico de las sociedades humanas, que, despecho de los antineologistas, es preciso llamar nacionalidad, ya que no tenemos en castellano una voz castiza para espresar aquella idea. (DP 21/9/1856: 1)

En los artículos siguientes, se recopilan interesantes ideas para la historia del léxico, como las referidas a los diferentes constituyentes integrados en épocas históricas concretas, los neologismos, de los que indica que «Todo neologismo (y téngase presente que sin neologismo no hay idioma posible) proviene de algún origen conocido, ó de una lengua estraña, ó de la onomatopeya, ó de alguna analogia mas ó menos perceptible, ó de la composicion de dos voces admitidas» (DP 19/10/1856: 1), y la compleja relación entre etimología, ortografía y pronunciación. En este último apartado, la consulta del Diccionario de Monlau es una constante. Aunque subyace la crítica, velada o no, al galicismo al que culpa, junto con el vulgarismo, de la decadencia de la lengua:

La lengua de Castilla camina rápidamente á una vergonzosa degeneracion. Nos quejamos, no sin razon, de los estragos que está haciendo en ella el policismo. El vulgarismo los hace mayores y mas degradantes. Lo que prueba la introduccion de palabras francesas, es que nos hemos familiarizado con la literatura de un pueblo que se nos ha adelantado en la carrera de la civilizacion; pero el vulgarismo denota un retroceso hacia el estremo contrario. La eliminacion de los elementos etimológicos viene á ser como la ingratitud del hombre de raza ilustre que arroja al fuego los retratos de sus progenitores, el esceso de sus armas y su árbol genealogico. (DP 26/10/1856: 1)

Junto a las cuestiones teóricas que se han señalado, el comentario real sobre determinadas construcciones o usos en la lengua ocupa un lugar destacable, pues, en virtud de su extensión, se convierte en objeto descriptivo de algunas columnas periodísticas. Es el caso de «hacer el oso»:

En vano buscamos en el diccionario de la Academia este modismo tan admitido y generalizado ya, que todo el mundo echa mano de él cuando viene á pelo, y eso que

${ }^{20}$ Años después, en 1868, Antonio Fabié retomó esos asuntos en «El origen de las lenguas según los escritores españoles» ([RE] Revista de España 5/1868: 584-607), donde se decanta por hablar de ciencia del lenguaje, en vez de filología o lingüística continuando los preceptos de Müller. Este contexto de divulgación de conocimientos a través de la prensa permite aventurar que quizás fuera este el medio por el que tales llegaran a profesionales del mundo docente, como Pedro Muñoz y Peña, por ejemplo (Díez de Revenga y Puche 2010). 
mientras no se digne la Academia fijar su significación, no sabemos realmente cómo hacer uso de esa frase metafórica, condenada como otras muchas de constante y espresiva aplicacion, á no figurar jamás en el diccionario de la lengua castellana, solo porque los señores de la Academia no saben hacer nada, absolutamente nada, como no sea lo que vulgarmente se entiende por hacer el oso. ([Camorra] El Tío Camorra 17/11/1847: 1)

A la hora de datar esta construcción, el Corpus del nuevo diccionario histórico del español $(C D H)$ nos proporciona su uso en 1851 a través de las Fábulas en verso originales de Concepción Arenal: «De ese trabajo penoso/ Dejad la dura faena,/ Y dejad caer la arena/ O dirán que hacéis el oso». En el Corpus del español (CE) hallamos un texto de 1836, Clemencia de Fernán Caballero, que contiene esa estructura, aunque la fecha de publicación de la obra fue 1852 y no 1836: «te estás poniendo en ridículo; mira cómo se ríen; estás haciendo el oso - dijo a media voz un amigo suyo». La consulta de obras lexicográficas desde el Nuevo tesoro lexicográfico de la lengua española (NTLLE) permite comprobar que el diccionario académico la incluyó en 1884, aunque previamente lo había hecho Domínguez en 1853. Los datos corroboran la temprana localización de una construcción, de reciente incorporación en la lengua, mediante los recursos que aporta la prensa.

En el polo opuesto se encuentra el carácter arcaico que poseen determinados usos en ese momento y, por tanto, su uso se va desplazando hacia lo que se consideraría arcaísmos. Es el caso de las fórmulas «A los pies de $\mathrm{Vd}$.» y «Beso a Vd. la mano», utilizadas como título de la columna, que se perciben de la siguiente manera:

En el último número de EL SIGLO ILUSTRADO tuve el honor de hacer la guerra á la frase $V d$. dispense, y continuando mis belicosos instintos, tomo hoy mi afilada pluma contra este par de frases que ¡no solo son ridículas, sino que tienen más bemoles que una ópera de Verdi! Hoy todo el mundo tiene guerra declarada á la lengua española, desde los académicos de la lengua (jestofada!) hasta los novelistas noveleros [...] Figúrate, amado lector, que encuentras á una señorita amiga tuya, te quitas el sombrero, y haciendo un arco con tu cuerpo, dirás seguramente: - A los pies de Vd., Fulanita. La joven sonríe, y te contesta: ¡Beso á Vd. la mano!... ¿No es verdad que así sucedería? [...] que digas que estás á los pies de una mujer cuando estás de pié y á una vara de distancia, y que esa mujer diga que te besa la mano, cuando ni remotamente piensa en ello, comprenderás que no está bien. Esto de estar á los pies de una mujer, es muy grave. Implica y envuelve pensamientos muy hondos. El beso en la mano podría pasar; porque dicen que es signo de respeto, pero... siempre es un beso. $\mathrm{Y}$ escuso deciros la gravedad que tiene y las consecuencias que puede traer un beso. Así, pues, convencidos de que el saludaros así es una simpleza y una falta á la verdad, busquemos otras frases que reemplazar á las citadas. ([Siglo] El siglo ilustrado 26/1/1868: 6)

Desde el $C D H$ se observa que este tipo de saludos o despedidas se mantienen vigentes en escritos formales y parece decaer a partir de la mitad del siglo. ${ }^{21} \mathrm{Un}$ caso similar queda representado con respecto a la preposición so, cuya aparición

${ }^{21}$ Durante la primera mitad, los ejemplos se localizan en escritos de Leandro Fernández de Moratín Manuel Bretón de los Herreros o Mariano José de Larra, en donde aparecen personajes de un estrato social alto que mantienen en uso esa fórmula de tratamiento. 
decae notablemente en los textos durante el siglo XIX, a partir de los datos que nos arrojan los corpus consultados ( $C D H$ y $C E)$, aunque se mantuvo en estructuras fijas como «so pena». Ante estos hechos, la prensa proporciona datos para su consideración como arcaísmo:

En todos los periódicos hemos leído en estos ó parecidos términos la siguiente noticia: "Guernica 6 de julio. Se ha verificado hoy la solemne apertura de las juntas generales so el árbol foral de Guernica." ¿Conque so el árbol? Vean ustedes; iy sería tan fácil, tan lógico y tan gramatical decir debajo! ¿Por qué han de insultar estos señores á la lengua española cada vez que se reúnen á celebrar sus juntas? ([Nación] La nación 12/7/1868: 4)

\subsection{La lengua como pretexto de la noticia}

La situación del idioma español puede ser objeto de comentario en el seno de un periódico, a pesar de que la noticia o columna aborde cualquier temática diferente a la de carácter lingüístico estrictamente. Si con anterioridad se ha observado la importancia adquirida por la noticia de la lengua, en sus más diversas facetas, ahora se comprobará cómo esas inquietudes se intercalan en aquellos textos alejados de contenido gramatical. En ambos casos, destaca el interés suscitado por el debate lingüístico en los espacios de opinión cada vez más generales y aceptados por la sociedad decimonónica. Tales perspectivas se brindan por escritores o redactores que, como afirma Puche (2019: 127), «sin formación lingüística, sienten preocupación por ese bien patrimonial intangible, en otras, sin embargo, quienes sí disponen de criterios y de formación académica exponen sus argumentos y teorías a través de las páginas de la prensa».

Con los antecedentes expuestos, ha quedado mostrada la reacción hacia los elementos foráneos, sobre todo de procedencia francesa, que implican una corrupción del idioma. Ante ello, surgen defensas y apologías del español (Puche 2017a) o críticas a las malas traducciones (Puche 2017b), sobre todo francesas y literarias, pues parece mostrarse cierta admiración cuando el texto es de naturaleza científica dado el avance que supone para el conocimiento. ${ }^{22}$ En consecuencia, ante una obra literaria se puede hallar comentarios como el siguiente:

Nada de estraño tiene, por consiguiente, que las obras del día sobre carecer de plan abunden en incorrección y desaliño. Por otra parte contaminado el idioma, con la lectura y traducciones francesas, va perdiendo aquella tersa, limpia y castiza elocución, de que tan preciosas muestras nos ofrecen las obras de nuestros buenos prosistas del siglo décimo sesto. Empedrada la frase castellana de galicismos y sometida á una sintaxis viciosa, apenas conserva ya el número y donaire que le son propios. Díganlo las palabras favoritas de la moda, debutar, abordar, gubernamental, oposicionista, fraccionamiento, y otras muchísimas, cuyo catálogo forma el moderno diccionario ${ }^{23}$ Franco-Hispano. Tan mal parado anda el

22 Véase también Rivas (2016), donde se muestra el análisis de la información y debate lingüístico contenido en la Gaceta de Bayona durante el primer tercio del siglo XIX.

${ }^{23}$ Nótese que en este contexto «diccionario» se utiliza para referirse al léxico disponible de una comunidad de hablantes. No obstante, el estudio de otros tipos textuales ofrece resultados en los 
idioma de Cervantes que se tendría por cosa rancia y mal sonante decir hablando de un escrito, en lugar de el fondo y la forma el concepto y la espresion. Ni mejor recibido seria, imprenta en vez de prensa, tripulación en vez de equipage, Dios en vez de Ser Supremo. En cambio asi en prosa como en verso campean hacinadas metáforas incomprensibles, hipérboles y antitesis con un sabor gongoresco de mal gusto. (Clamor 8/5/1844: 4)

En el periodo acotado se constata que, aunque el galicismo sea el elemento que mayor carga crítica genera, los anglicismos comienzan a tener un índice de presencia notable a partir de los años centrales del siglo. Se localizan tanto en el ámbito político: «la convocación de las cámaras, para pedirlas, como de razón, un 'voto absolutorio', ó sea lo que ya en todas partes se designa con el anglicismo de un 'bill de indemnidad'» ([Corona] La Corona 10/12/1857: 5), como en el doméstico o cotidiano: «la sociedad española sigue en marcha y no se ha sentado todavía, es sin duda porque no se le ha ofrecido un asiento que pueda en realidad, aunque usando de un anglicismo, llamarse confortable» ${ }^{24}$ (América 8/3/1858: 18). El préstamo de esta procedencia comienza a percibirse también como «inútil», en el momento en que existen palabras castellanas para designar los referentes aportados por las correspondientes inglesas: «Hablamos de escentricidad ${ }^{25} \mathrm{y}$ escéntricos, en una acepción moral exótica [...] a qué usar (se nos dirá), de un anglicismo inútil que pudiera sustituirse en castizo castellano con las palabras extravagancia y extravagantes» ([Museo] El museo universal 3/6/1860: 3). Ante estos hechos se percibe que los elementos léxicos adquieren mayor protagonismo en este tipo de comentarios, denominados aquí «indirectos». Esto se trasluce a todas las esferas de actuación, desde el préstamo, como se ha visto, hasta las creaciones recientes, motivadas por el contexto histórico y crítico a veces. En consecuencia, se localizan formaciones neológicas, de autor conocido, por lo que podríamos considerarlas creadas bajo la onomaturgia (Álvarez de Miranda 2008: 140), como el verbo pidalear: ${ }^{26}$

que ya se había producido una identificación entre lengua y diccionario, como ha advertido Garriga Escribano (2018: 315) en las traducciones que llevaron a cabo algunos químicos españoles.

${ }^{24}$ Su antónimo también se localiza en «Aqui los tenemos algún tanto cabizbajos, presa de la reacción que traen consigo las grandes esperanzas defraudadas y bastante inconfortables, si se nos permite este anglicismo» (Heraldo 17/10/1851: 4). Confortable se incorporó a los repertorios lexicográficos en 1917, Alemany y Bolufer, y 1927, en el caso de la obra académica, mientras que inconfortable todavía no ha encontrado su hueco en este tipo de obras.

${ }^{25}$ Con respecto a estas voces, se produce un caso similar a las anteriormente comentadas. El diccionario académico las introdujo en 1925, aunque Zerolo, 1895 (NTLLE), hace la siguiente observación: «Muchos usan malamente esta palabra en el sentido de extravagancia, originalidad. Es un galicismo».

${ }^{26}$ En aquellos periódicos no afines a Pedro José Pidal se utilizó con frecuencia, hasta tal punto que, a principios del siglo XX, en la semblanza que redactó Augusto Conte, leemos: «Otro defecto de Pidal era cierta falta de aplicación á los trabajos de su Secretaría. Sus émulos llegaron á formar con su apellido el verbo «pidalear», usándolo como sinónimo de hacer poco, y los oficiales del ministerio le acusaban de que, en lugar de despachar los negocios corrientes, se estaba horas enteras encerrado en su despacho con el subsecretario, D. Leopoldo de Cueto, literato como él y 
Leemos en el Heraldo: El idioma español se ha enriquecido con un verbo de tal manera espresivo, que en cuanto lo vean nuestros lectores se quedarán admirados de la exactitud y precisión con que espresa la idea que quiere significar. Este verbo es Pidalear, esto es, no hacer nada. Aun cuando antes teníamos los verbos holgar, holgazanear y otros, ninguno espresaba esactamente la idea de no hacer nada, absolutamente nada: pero hé aquí que a la academia de la lengua se la presenta el medio de llenar este vacio inmortalizando al mismo tiempo el nombre de uno de sus individuos. De todos modos el verbo Pidalear, tenga ó no el exequátur de la academia, estamos seguros de que se aclimatará en nuestra patria, y acaso logre ser trasplantado á otras naciones. (Clamor 23/9/45: 4)

El léxico puede ser estudiado desde diferentes perspectivas a través de las fuentes periódicas, además del préstamo y las creaciones ocasionales, a veces. La divulgación en sus páginas de voces científicas (Puche 2011), de términos del deporte (Nomdedeu 2017), de aportaciones etimológicas ${ }^{27}$ o de precisiones semánticas, ${ }^{28}$ incluso la introducción de variedades dialectales (Pons 2000), confirma la importancia de la prensa para completar esa parte de nuestro pasado lingüístico. Los comentarios sobre ortografía, funcionamiento sintáctico, uso de determinadas partículas también se deslizan en este tipo de noticias, aunque no son tan abundantes. Sin embargo, otra de las facetas que se puede extraer de estos textos consiste en la propia evolución interna del idioma, sobre todo en el plano sintáctico y en el concerniente a las tradiciones discursivas, en los que, por motivos de espacio, no se puede ahondar en estos momentos. Con el fin de señalar la riqueza del periódico para el estudio de la lengua desde estos ámbitos, se puede leer el fragmento que se adjunta a continuación. A partir de un debate

poeta por añadidura, disputando sobre quién era Tomé Burguillos ú otra cuestión cualquiera de curiosidad literaria» ([Época] La Época 22/11/1901: 1).

${ }^{27}$ Los redactores suelen utilizar Autoridades como punto de referencia: «Sobre la voz naipe también se ha discurrido largamente asignándola diferentes etimologías; pero la que comunmente se cree mas probable y que confirma el diccionario de nuestra academia española, es la de haberse llamado así por la primer (sic) cifra que se les puso que fue una N. y una P. iniciales de Nicolao Pepin, inventor de su fabricación» (Pintoresco 30/10/1836: 7).

${ }^{28}$ Generalmente suelen crearse modificaciones de significado por algún matiz irónico o satírico. Por ello se busca una relación sinonímica entre latinazo y latinajo: «Últimamente nos atreveremos á emitir nuestro humilde parecer, creyendo que decir latinajos en vez de latinazos (a) ó vice-versa, no es cosa que pueda redundar en favor ó en contra de los intereses de la provincia que tanto alarde ha hecho V. de defender [...] (a) LATINAJO. El latín malo y macarrónico. (Véase el Diccionario de la lengua castellana compuesto por la Real Academia española. LATINAZO. No existe semejante palabra en el Diccionario, ni la conocen los que saben el castellano» ([Balear] $E l$ balear 9/7/1848: 3). De hecho, se publicó una columna sobre la concepción de las palabras en ese momento: «Las letras son unos signos de que nos valemos para la formación de las palabras, y estas unas voces que tienen una significación propia y sirven para espresar los conceptos, aunque yo mas bien creo que sirven para ocultarlos ó disfrazarlos, así como no dudo que muchas voces aisladas no tienen concepto, que otras dicen mas de lo que significan, y que otras espresan lo contrario de su valor, sin que para ello nos valgamos de ninguna clase de puntuación, ni aun de la académica, que es la que anatematiza las innovaciones, cuando llevan este nombre: en fin, palabras hay que á primera vista parecen palabras, pero que no lo son, asi como hay hombres que se parecen al hombre tanto, que engañarían á cualquiera» (Clamor 27/10/1844: 3). 
político se sugieren diversas ideas sobre la lengua y, además, se localizan las estructuras «por lo bajo», que parece generalizarse en el siglo XIX, sobre todo a partir de 1830, cuando se hace acompañar de alguno de los verba dicendi (decir, hablar, murmurar, etc. $)^{29}$ y «una salida de cajón», también propia de este siglo, como equivalente a «salida de tono» $\mathrm{O}$ «sacar de traste». ${ }^{30}$ Mientras que la primera conserva vitalidad hasta el presente, la segunda no sobrepasó apenas el umbral del siglo XX:

Dijo el susodicho marqués «yo retiro mi enmienda, para que el señor Barrio Ayuso no se enfade.» Y este le contestó por lo bajo, «bien podía Vd. hablar con modo.» El señor marqués habla con modismos, pero son franceses [...] Con motivo de haber dicho en el Senado el señor marqués de Albaida (padre del señor Orense) en la sesión de ayer, y dirijiéndose al señor ministro de Hacienda con motivo de la preferencia que daba al clero sobre otras clases, que algo tenía el agua cuando la bendecían, se levantó el besugo con todas sus escamas, y colérico y enojado retó al marques á que esplicara lo del agua. Y dijo el marqués, que aquello del agua era una salida de cajón, y que el que quisiera esplicaciones las buscara en el diccionario de la lengua. Y salióse de sus casillas el ministro de las hordas fortuitas y levantando las manos al cielo, ensanchó sus dilatadas fauces, sacó los ojos de sus órbitas, y con voz de bajo catedral esclamó de esta manera «Si el señor diputado....-Yo no soy diputado, que soy senador, dijo el marqués. - Si el señor senador no esplica esas palabras, lo tomaré por donde quema; (Risas.) porque el Senado... Yo no me quemo, repuso el marqués. - Pues yo le desmiento, yo le desmiento, yo le desmiento. Levantóse el marqués, y con ademan tranquilo y sereno, díjole por toda satisfacción. - Es que eso no se puede desmentir. (Clamor 12/2/1845: 4)

\section{A MANERA DE CONCLUSión}

El análisis de la prensa correspondiente a un periodo concreto, el comprendido entre 1833 y 1868, arroja importantes datos para corroborar la importancia de este medio efímero para la reconstrucción y el mejor conocimiento del pasado lingüístico del español. Es esta una época políticamente compleja y culturalmente apasionante por la propagación de las ideas románticas, principalmente, así como por la extensión social obtenida por el periódico que multiplicó los lectores de forma abrumadora. Sus páginas facilitaban la distribución de obras literarias y la adquisición de conocimientos de todo tipo, científicos, políticos, históricos y también lingüísticos, factor este que se vio favorecido por la inclusión de cartas, réplicas o comentarios de estos contenidos, mostrando la interacción social a la que estaba predispuesto. Los datos incluidos aquí permiten reanalizar desde otra óptica la influencia de la Real Academia y de los académicos en la sociedad

${ }^{29}$ La consulta del CDH arroja un primer ejemplo con este valor a finales del siglo XVIII en un texto de Tomás de Iriarte. Después, será a partir de 1830 cuando sea una estructura generalizada, después de haber fijado su uso como unidad del discurso repetido.

${ }^{30}$ Los únicos ejemplos encontrados pertenecen a la prensa decimonónica. Incluso existe una composición poética, difundida desde sus páginas, que incluye lo siguiente: «Y es en circunstancia tal/ la salida de cajón/ decirse ambos al sacarse/ todos los trapos al sol» ([RB] Revista barcelonesa 18/4/1847: 1). 
decimonónica, la difusión de trabajos de corte gramatical y la constante elaboración de materiales, la propagación de nuevas corrientes lingüísticas procedentes de Europa, el concepto de lengua y la percepción del español en ese momento, la actitud ante la influencia extranjera en estos asuntos, la presencia de nuevas estructuras frente a la decadencia en el uso de otras, etc. Todo ello se ha realizado a través de testimonios directos e indirectos, es decir, lingüísticos y metalingüísticos que facilitan el acceso a la diacronía del español desde una perspectiva externa e interna. La utilidad de lo efímero, en el soporte y no tanto en la conciencia colectiva, abre numerosas vías para conocer en mayor profundidad una época cercana en el tiempo, pero lejana de algunos intereses y para que «los historiadores hagan aprecio de nuestra época á menos que no empleen la riqueza de la lengua española y la abundancia de nuestros recuerdos» (Clamor 31/5/1844: 4).

\section{BIBLIOGRAFÍA}

HEMEROGRAFÍA

[Palma] Almacén de frutos literarios del Semanario de Palma, Palma de Mallorca, 1841-1845. Biblioteca Virtual de Prensa Histórica <prensahistorica.mcu.es> [Consulta: enero 2019].

[DP] Diario de Palma, Palma de Mallorca, 1851-1856. Biblioteca Nacional de España (Hemeroteca Digital: <hemerotecadigital.bne.es>) [Consulta: enero 2019].

[Balear] El balear, Palma, 1849-1856. Biblioteca Nacional de España (Hemeroteca Digital: $<$ hemerotecadigital.bne.es>) [Consulta: enero 2019].

[Clamor] El clamor público, Madrid, 1844-1864. Biblioteca Nacional de España (Hemeroteca Digital: <hemerotecadigital.bne.es $>$ ) [Consulta: enero 2019].

[Español] El Español, Madrid, 1835-1848. Biblioteca Nacional de España (Hemeroteca Digital: <hemerotecadigital.bne.es>) [Consulta: enero 2019].

[Fraile] El Fraile, Madrid, 1869-1870. Biblioteca Nacional de España (Hemeroteca Digital: $<$ hemerotecadigital.bne.es>) [Consulta: enero 2019].

[Libertad] El genio de la libertad, Palma, 1839-1857. Biblioteca Nacional de España (Hemeroteca Digital: <hemerotecadigital.bne.es>) [Consulta: enero 2019].

[Heraldo] El Heraldo, Madrid, 1842-1854. Biblioteca Nacional de España (Hemeroteca Digital: $<$ hemerotecadigital.bne.es $>$ ) [Consulta: enero 2019].

[Museo] El museo universal, Madrid, 1857-1869. Biblioteca Nacional de España (Hemeroteca Digital: <hemerotecadigital.bne.es>) [Consulta: enero 2019].

[Popular] El popular, Madrid, 1846-1851. Biblioteca Nacional de España (Hemeroteca Digital: <hemerotecadigital.bne.es>) [Consulta: enero 2019].

[Siglo] El siglo ilustrado, Madrid, 1867-1868. Biblioteca Nacional de España (Hemeroteca Digital: <hemerotecadigital.bne.es>) [Consulta: enero 2019].

[Tiempo] El Tiempo, Madrid, 1845-1847. Biblioteca Nacional de España (Hemeroteca Digital: <hemerotecadigital.bne.es>) [Consulta: enero 2019].

[Camorra] El Tío Camorra, Madrid, 1847-1848. Biblioteca Nacional de España (Hemeroteca Digital: <hemerotecadigital.bne.es>) [Consulta: enero 2019]. 
[América] La América, Madrid, 1857-1886. Biblioteca Nacional de España (Hemeroteca Digital: <hemerotecadigital.bne.es>) [Consulta: enero 2019].

[Corona] La Corona, Barcelona, 1857-1868. Biblioteca Nacional de España (Hemeroteca Digital: $<$ hemerotecadigital.bne.es $>$ ) [Consulta: enero 2019].

[Época] La Época, Madrid, 1849-1936. Biblioteca Nacional de España (Hemeroteca Digital: $<$ hemerotecadigital.bne.es $>$ ) [Consulta: enero 2019].

[Ilustración] La Ilustración, Madrid, 1849-1857. Biblioteca Nacional de España (Hemeroteca Digital: <hemerotecadigital.bne.es $>$ ) [Consulta: enero 2019].

[Nación] La Nación, Madrid, 1849-1873. Biblioteca Nacional de España (Hemeroteca Digital: $<$ hemerotecadigital.bne.es $>$ ) [Consulta: enero 2019].

[RB] Revista barcelonesa, Barcelona, 1846-1847. Biblioteca Nacional de España (Hemeroteca Digital: <hemerotecadigital.bne.es $>$ ) [Consulta: enero 2019].

[RE] Revista de España, Madrid, 1868-1894. Biblioteca Nacional de España (Hemeroteca Digital: <hemerotecadigital.bne.es>) [Consulta: enero 2019].

[RL] Revista literaria de El español Semanario pintoresco español, Madrid, 1845-1847. Biblioteca Nacional de España (Hemeroteca Digital: <hemerotecadigital.bne.es $>$ ) [Consulta: enero 2019].

[Pintoresco] Semanario pintoresco español, Madrid, 1836-1847. Biblioteca Nacional de España (Hemeroteca Digital: <hemerotecadigital.bne.es>) [Consulta: enero 2019].

\section{FUENTES BIBLIOGRÁFICAS}

Álvarez De MirandA, P. (2009), «Neología y pérdida léxica», en Panorama de lexicología, de Miguel, E. (ed.), Barcelona, Ariel, 133-158.

Álvarez DE MirandA, P. (2011), En doscientas sesenta y tres ocasiones como esta. Discurso leído el día 5 de junio de 2011 en su recepción pública, Madrid, Aguirre Campano.

BARRERA, C. (ed.) (2000), El periodismo español en su historia, Barcelona, Ariel Practicum.

BATTANeR, P. (1977), Vocabulario político-social en España (1868-1873), Madrid, Real Academia Española.

BiblioteCA NACIONAL DE EsPAÑA. Hemeroteca digital [en línea], Madrid, 2019 [Consulta: 15 de enero de 2019]. Disponile en: <http://hemerotecadigital.bne.es/index.vm>.

BorReguero ZUlOAGA, M. (2012), "Análisis del discurso», en Reflexión lingüística y lengua en la España del siglo XIX, Zamorano, A. (dir.), Muenchen, Lincom Europa, 301-337.

CALERO VAQUeRA, Ma L. (2014), «En los orígenes del concepto 'ideología'. De la Filosofía a la Lingüística, del individuo a la sociedad», Boletín Hispánico Helvético, 23, 109140.

CALVO LóPez, C. (2002), «Románticos españoles y tragedia inglesa: el fracaso del Macbeth de José García de Villalta», en Neoclásicos y románticos ante la traducción, Palacios Bernal, C., Lafarga, F. y Saura, A. (eds.), Murcia, Universidad de Murcia, 59-72.

CAMPOS SOUTO, M. (2018), «Bibliotecas y hemerotecas digitales en el NDHE», Cuadernos del Instituto Historia de la Lengua, 11, 237-255.

ClAVERÍA NADAL, G. (2016), De vacunar a dictaminar: la lexicografía académica decimonónica y el neologismo, Madrid, Iberoamericana Vervuert.

CORNEJO, J. (2011), «Traduciendo desde el exilio (3): José García de Villalta», El Trujamán. Revista diaria de traducción, s. p. [en línea]. Centro Virtual Cervantes: Instituto 
Cervantes, 16 de junio de 2011 [Consulta: enero de 2019]. Disponible en: $<$ https://cvc.cervantes.es/trujaman/anteriores/junio_11/16062011.htm>.

COTELO GARCíA, R. (2019), «De ballenas a bikinis: las fuentes digitales de prensa como un recurso innovador e imprescindible en la elaboración del Nuevo diccionario histórico del español (NDHE)», Historia e historiografía de los diccionarios del español. Anejo 11 de Normas, 131-141.

$(C E)$ = DAVIES, M., Corpus del español, [en línea]. Brigham Young University, USA: National Endowment for the Humanities, 2016 [Consulta: 20 de marzo de 2019]. Disponible en: <http:www.corpusdelespanol.org>.

Díez De Revenga TORRes, P. y PuCHe LorenZO, M. Á. (2010), Discurso sobre el origen y progreso histórico de la lengua castellana de Pedro Muñoz y Peña. Edición y estudio lingüístico, Murcia, Universidad de Murcia.

DURÁN LÓPEZ, F. (2016), "Andrés Bello contra José Joaquín de Mora en veintisiete palabras: una polémica chilena en 1830», en Estudios sobre Filología Española y exilio en la primera mitad del siglo XIX, Durán López, F. y Gaviño Rodríguez, V. (eds.), Madrid, Visor Libros, 503-536.

FUENTES ARAGONÉS, J. F. Y FERNÁNDEZ SEBASTIÁN, J. (1997), Historia del periodismo español: prensa, política y opinión pública en la España contemporánea, Madrid, Síntesis.

GARCíA FOLGADO, Mํㅗ J. (2016), «Lengua y enseñanza en el exilio: Felipe Senillosa y José Joaquín de Mora en América», en Estudios sobre Filología Española y exilio en la primera mitad del siglo XIX, Durán López, F. y Gaviño Rodríguez, V. (eds.), Madrid, Visor Libros, 479-501.

GARRIGA ESCRIBANO, C. (2018), «Las voces de la Química», en El diccionario de la Academia en el siglo XIX: la 5 a edición (1817) al microscopio, Clavería, G. y Freixas, M. (coords.), Madrid, Arco Libros, 313-337.

GAViÑo RodrígueZ, V. (2016), «José Joaquín de Mora en el exilio londinense. El Catecismo de gramática castellana», en Estudios sobre Filología Española y exilio en la primera mitad del siglo XIX, Durán López, F. y Gaviño Rodríguez, V. (eds.), Madrid, Visor Libros, 367-394.

GÓMEZ DE ENTERRÍA, J. (1993), «Las lenguas especiales en la prensa diaria», en Actas de las II Jornadas de Lenguas para Fines Específicos, Barrueco, S., Hernández, E., Sánchez de Nieva, Mํㅣ. y Sierra, L. (eds.), Alcalá de Henares, Universidad, 345-352.

Gómez ÍMAZ, M. (2008), Los periódicos durante la Guerra de la Independencia (1808-1814), Sevilla, Renacimiento.

GUTIÉRREZ CUADRADO, J. (1988), «La lengua en los anales de primera enseñanza: descripción de un ejemplo de la ideología, ciencia y cohesión grupal de la prensa decimonónica», en Actas del II Simposio de Enseñanza e Historia de las Ciencias, Blanco Abellán, M. (coord.), Pamplona-Iruña, SEHCYT, 143-172.

LARA, L. F. (2015), Historia mínima de la lengua española, México, El Colegio de México.

LUIS, C. R. (2010), «Cuando pensar era sentir: una mirada a la Gramática de Destutt de Tracy», Revista argentina de historiografía lingüística, 2(1), 39-53.

Ministerio De Cultura y DePORTE. Biblioteca Virtual de Prensa Histórica [en línea]. Madrid: Ministerio de Educación y Cultura, Gobierno de España [Consulta: 18 de enero de 2019]. Disponible en: <https://prensahistorica.mcu.es/es/inicio/inicio.do $>$.

Nomdedeu Rull, A. (2017), «El corpus de textos periodísticos en el Diccionario Histórico de Términos del Fútbol (1890-1899)», en El diccionario en la encrucijada: de 
la sintaxis y la cultura al desafío digital, Garriga Escribano, C. (coord.), Santander, Escuela Universitaria de Turismo Altamira, 665-668.

ORDINE, N. (2013), La utilidad de lo inútil. Manifiesto, Barcelona, Acantilado.

Poch Olivé, D. (2018), «El interés por el lenguaje en La España Moderna», en La España Moderna (1889-1914). Aproximaciones literarias y lingüísticas a una revista cultural, Amores, M. y Ferrús, B. (eds.), Madrid, Iberoamericana Vervuert, 117-137.

Pochat Muro, Mํㅡㄴ T. (2015 [1982]), La creación léxica en español a través de la prensa del siglo $X I X$, tesis doctoral, Madrid, Universidad Complutense.

PONS RODRÍGUEZ, L. (2000), «La escritura en andaluz en tres periódicos del XIX: El Tío Tremenda (1814, 1823), El Anti-Tremenda (1820) y El Tío Clarín (1864-1871)», Philologia Hispalensis, 14, 77-98.

PuCHE LORENZO, M. Á. (2011), «La minería a través de la prensa: la especialidad en el filón de la lengua», en Nuevas claves para el estudio de la lengua española: usos especializados en la comunicación, Díez de Revenga, P. y Puche Lorenzo, M. Á. (eds.), Murcia, Universidad de Murcia (eds.), 112-128.

Puche LorenZO, M. Á. (2017a), «Las apologías de la lengua en el siglo XIX. Las controversias de una herencia y los retos decimonónicos», en Herencia e innovación en el español del siglo XIX, Carpi, E. y García Jiménez, R. (eds.), Pisa, Pisa University Press, 245-262.

Puche Lorenzo, M. Á. (2017b), «¿Por qué (no) traducir del francés en el siglo XIX? El protagonismo del español entre traductores y editores», en Reconstruyendo el pasado de la traducción (II). A propósito de las imprentas/editoriales y de las obras científicas y técnicas traducidas del francés al español (siglo XIX), Pinilla, J. y Lepinette, B. (eds.), Granada, Comares, 243-258.

PUCHE LORENZO, M. Á. (2019), «El periodismo del siglo XIX ante la lengua española», en Ideologías sobre la lengua y medios de comunicación escritos. El caso del español, Marimór, C. y Santamaría, I. (coords.), Berna, Peter Lang, 115-130.

$(C D H)=$ REAL ACADEMIA ESPAÑOLA. Corpus del nuevo diccionario histórico del español, Madrid [Consulta: 20 de marzo de 2019]. Disponible en: <www.rae.es>.

$(N T L L E)=$ REAL ACADEMIA ESPAÑOLA. Nuevo tesoro lexicográfico de la lengua española, Madrid [Consulta: 7 de abril de 2019]. Disponible en: <www.rae.es>.

RISCO, A. (1972), «Las ideas lingüísticas de Larra», Boletín de la Real Academia Española, 52(197), 467-502.

RIVAS ZANCARRÓN, M. (2016), «La lengua y sus espacios de opinión en el exilio de los afrancesados. La Gaceta de Bayona», en Estudios sobre Filología Española y exilio en la primera mitad del siglo XIX, Durán López, F. y Gaviño Rodríguez, V. (eds.), Madrid, Visor Libros, 73-104.

RIVAS ZANCARRÓN, M. (2018), «La forma de los tipos gráficos como instrumento para la expresión de actitudes lingüísticas en la prensa costarricense del siglo XIX», Boletín de filología (Universidad de Chile), 53(1), 237-275.

RIVAS ZANCARRÓN, M. (2019), «Actitudes explícitas ante el resalte gráfico en la tradición discursiva periodística española de los siglos XVIII y XIX», Anuario de Letras: Lingüística y filología, 7(1), s. p.

SELLÉS, E. (1895), Del periodismo en España. Discursos leídos ante la Real Academia Española en la recepción pública de Don Eugenio Sellés el día 2 de junio de 1895, Madrid, Imprenta de la Revista de Navegación y Comercio.

SEOANE, M ${ }^{a}$ C. (1983), Historia del periodismo en España. II: El siglo XIX, Madrid, Alianza. 
YNDURÁIN, F. (1955), «Refranes y Frases hechas en la estimativa literaria del siglo XVII», Archivo de Filología Aragonesa, 7, 103-130. 